\title{
Application of Internet Technology in Mental Health Education of College Students*
}

\author{
Yanqing Zeng \\ Xi'an FanYi University \\ Xi'an, China
}

\begin{abstract}
This paper carries out the research on the application of Internet technology in the mental health education of college students, mainly to clarify the importance of Internet technology in the mental health education of colleges and universities and its specific application situation. In the information era where economic and cultural prosperity flourishes, talent based on university students has become an important foundation for national development. The mental health of college students has increasingly attracted wide attention from all walks of life. Many colleges and universities use Internet technology to improve the level of mental health education for college students. This article first analyzes the advantages of applying internet technology in college students' mental health education. Secondly, it discusses the common forms of Internet technology in the mental health education of college students. Finally, focusing on the example of "one-stop" mental health education service supermarket, it analyzes its application in the mental health education of college students.
\end{abstract}

Keywords-Internet technology; college students; mental health education

\section{INTRODUCTION}

In recent years, China has gradually entered the era of information networking. On this basis, Internet technology has been widely applied to various fields under the continuously updating situation. Especially in the field of education, the application of Internet technology can effectively improve the level and efficiency of education. At present, more and more colleges and universities are strengthening the application of Internet technology when they conduct mental education courses. From a certain perspective, the application of Internet technology in mental health education of college students can lay a solid foundation for the construction of good health psychology for college students based on optimizing the methods and environment of mental health education for college students. Therefore, this article carries out the exploration related to Internet technology and mental health education and has

*This article is the research achievement of Shaanxi Provincial Social Science Fund Project "Humanistic Care and Psychological Consultation in the Ideological and Political Education for College Students in Shaanxi Province" (Project No. 2014M04).

This article is the research result of Xi'an Science and Technology Association's 2018 annual key academic exchange and science and technology service project: series education activities for "post-1990s" college students' mental health". realistic research value.

\section{ADVANTAGES OF APPLICATION OF INTERNET TECHNOLOGY IN MENTAL HEALTH EDUCATION FOR COLLEGE STUDENTS}

\section{A. Breakthroughs in the Limitation of Space and Time}

At present, Internet technology is widely used in the mental health education of college students [1]. Its main advantages are highlighted by the fact that the application of Internet technology has made the mental health of college students' break through the limitation of space and time. In the traditional mental health education of college students, mental health education knowledge courses and mental counseling courses are often used to solve the mental health problems of college students. Therefore, there is a certain limitation to the scope and time of its education. In the information era, the application of network technology enables both sides in the information exchange to complete the dialogue at any place and at any time with the support of Internet technology. With this flexible teaching method, college students can receive psychological education in time so as to lay the foundation for promoting the mental health of college students.

\section{B. The Method and Environment Conducive to Optimizing Mental Health Education}

The application of Internet technology in the mental health education of college students also plays an important role in optimizing the methods and environment of mental health education in universities [2]. The application of Internet technology in the psychological teaching of college students can highlight the main status of college students and the assistant role of teachers. Teachers use diverse mental teaching resources to stimulate students' interest in learning knowledge about mental health education. In addition, with computer multimedia and other means, teachers can instruct college students to independently learn mental health education knowledge online and use WeChat, Zhihu, or blog to ask questions about mental health problems. It can be seen that with the help of Internet technology, a good mental health education environment can be created for college students. 


\section{ANALYSIS OF COMMONLY USED FORMS OF INTERNET TEChNOLOGY IN MENTAL HEALth EdUCATION FOR COLLEGE STUDENTS}

\section{A. Implementation of Exchange and Interaction on Computer Network Platform}

In the mental health education of college students, there are many forms of application of Internet technology. Using Internet technology to carry out computer network platform interaction is a common form [3]. During the period of mental health education, college teachers can strengthen the collection of information on college students and build mental health records for students. On this basis, according to the psychological characteristics and cognitive conditions of college students, teachers can make comprehensive evaluation and classification, and establish a dynamic monitoring system for different students. At the same time, with the support of internet technology, a psychological consultation website can be established to answer questions for college students. In the interaction and communication through computer network platforms, the commonly used interaction and communication methods include WeChat, QQ, e-mail, and blogs. The teacher guides students according to their mental problems, combined with psychological knowledge and their own experience.

\section{B. Development of Psychological Health Education Network Resources}

University teachers can use Internet technology to develop network resources of mental health education from a multiple perspective [4]. In the process of psychological health education for college students, the traditional teaching methods mainly use textbooks, with relatively single teaching contents, and the cases listed in textbooks lack timeliness. In the information age, college teachers can use Internet technology to guide college students to collect mental health education knowledge content on the Internet, understand real-time cases related to mental health, and enrich their mental health education knowledge. In addition, teachers can also use Internet technology to achieve the production of knowledge content of mental health education. Through small and elaborate videos in various forms, the mental health education knowledge can be expounded vividly and attracts the attention of university students.

\section{Construction of "One-stop" Mental Health Education Service Supermarket}

At present, in the implementation of mental health education, many colleges and universities also adopt the education approach of "one-stop" mental health education services supermarket [5]. The "one-stop" mental health education service supermarket as a website, mainly integrates various discipline theories and enables students to use various organs to master psychological knowledge and seek suitable ways to vent their emotions and improve their psychological problems through communication with others. In essence, the "one-stop" mental health education service supermarket website is the way for students to complete the study of knowledge of mental health education and improve their mental health through the approach of "others help, mutual help, and self-help". With the help of such Internet technology websites, the student-oriented teaching principles have been fully highlighted in light of students' actual conditions and needs.

\section{EXAMPLE OF "ONE-STOP" MENTAL HEALTH EDUCATION SERVICE SUPERMARKET IN MENTAL HEALTH EDUCATION FOR COLLEGE STUDENTS}

\section{A. Construction of "One-stop" Mental Health Education Service Supermarket}

1) Purposes of service supermarket construction: A university in Shandong Province used the "one-stop" mental health education service supermarket when carrying out mental health education for college students. In the construction of the platform of mental health education service supermarket, the school teachers expounded the purpose of the construction of service supermarket through the analysis of the importance of the "one-stop" mental health education service supermarket and the knowledge of mental health education. The psychological teacher pointed out that the purpose of the establishment of the service supermarket is clear, including three aspects [6]. First is the purpose of serving supermarkets. It is to help students master the relevant knowledge of psychology more quickly, so that students can correctly understand and accept themselves. Second is the object of service supermarkets. It provides a relatively stable psychological reading room for psychological counseling teachers and course teachers at universities and provides psychological counseling. Last is the function of the service supermarket It promote communication between college students and others based on self-help tutoring.

2) Design requirements for construction of service supermarket: When colleges and universities in Shandong Province built the "one-stop" mental health education service supermarket website, the requirements for the construction and design of service supermarkets were summarized from the perspective of college students' psychological problems and demand status. The psychological teachers in the university believe that the "one-stop" mental health education service supermarket is a platform serving psychological health education of college students, so the service design should be in line with the mental health status of college students. In the process of designing the website, the contents covered by the knowledge of mental health education show certain scientificity and standardability. The content is based on mental health knowledge and highlights the service nature of mental health knowledge. At the same time, the "onestop" mental health education service supermarket website constructed has a relatively fresh interface and highlights the characteristic of huge amount of information on mental health knowledge [7]. In addition, the mental health content 
set on the homepage of the website was designed with interesting and healthy dynamic knowledge points, which is more in line with the actual psychological needs of the college students.

3) Structure and principle of service supermarket construction: The "one-stop" mental health education service supermarket constructed by Shandong universities is a new type of computer new system. Through analysis of the service supermarket website constructed by the university, it is found that its internal structure is relatively complex [8]. Among them, there are much content such as the database, model library, and man-machine interface. In operation, the database mainly receives and modifies the data information of the management system; in the operation of the model library, it mainly stores and extracts the collected data information. With the help of the "onestop" mental health education service supermarket website, the psychological teacher can issue a command to inquire about the psychological problems of the university students on the man-machine interface. The database management system of the service supermarket website will automatically store the data in the database, extract the model from the model base by modifying the relevant data in the database and make corresponding operations to obtain the result of the operation. "Fig. 1" shows an operational diagram of Shandong University's “one-stop" mental health education service supermarket.

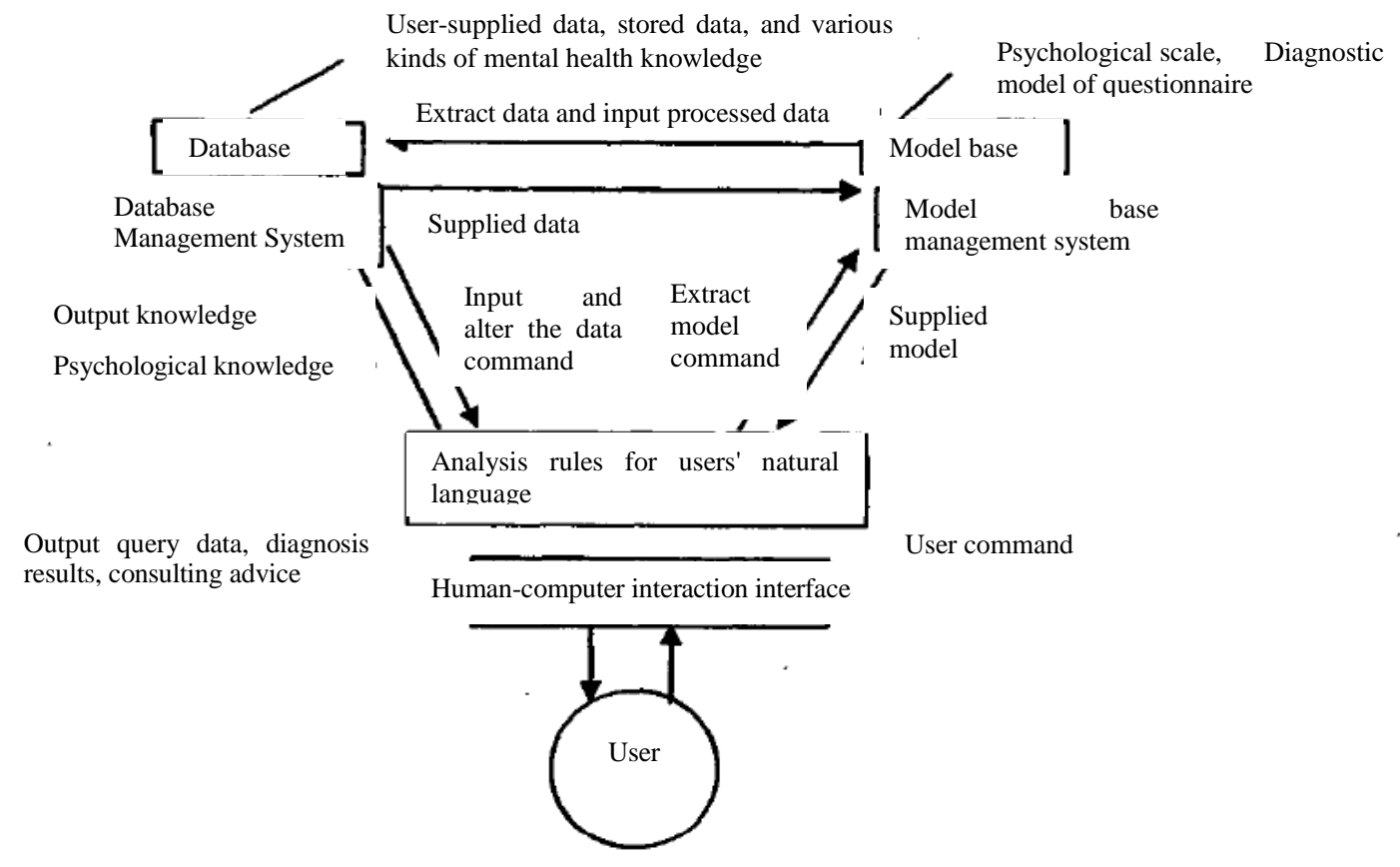

Fig. 1. The operational diagram of Shandong University's "one-stop" mental health education service supermarket.

\section{B. Platform of "One-stop" Mental Health Education Service Supermarket}

1) Storage-style network automatic service platform of service supermarket: The "one-stop" mental health education service supermarket website built by Shandong universities includes a storage-style network automatic service platform [9]. Under this service platform, its main core is "storage" and "self-service". Through the effective tracking and control of logistics and inventory, the entire educational chain of mental health issues can operate under a relatively stable working environment. With the aid of a storage-style network automatic service platform, "storage" is used as the basis for mental health education knowledge and technical support is adopted, including search engines, yellow pages of mental health issues, and dynamic web pages. On this basis, the "one-stop" mental health education service supermarket built by the university has seen a significant expansion of its virtual inventory, which has fundamentally promoted undergraduates to understand and recognize them based on their actual psychological conditions.

2) Participatory network mutual help assistance of service supermarket: The "one-stop" mental health education service supermarket website built by Shandong universities also includes the participatory network mutual assistance platform. The psychology teacher of the university pointed out that the core content of participatory network mutual assistance platform under the service supermarket is "emphasizing participation". With the help of the network mutual assistance platform, the university students can fully communicate and exchange with others on this platform, and effectively realize mutual assistance [10]. For example, under the participatory online mutual 
assistance platform, college students can make friends on the Internet platform with chat tools such as QQ, WeChat, and Netease, so that their inner feelings of loss and inferiority feeling have been greatly eased. During the chat on the Internet platform, by using the interesting psychological test, the college students' harmful psychological problems can be released, and through the provision of computer puzzle games, the psychological pressure of college students can be released.

\section{PRECAUTIONS FOR THE CONSTRUCTION OF “ONE- STOP” MENTAL HEALTH EdUCATION SERVICE SUPERMARKET}

\section{A. Website Maintenance and Resource Sharing}

Shandong universities recognized the importance of website maintenance and resource sharing during the construction of "one-stop" mental health education service supermarkets. The psychological teacher pointed out that the teaching resources for mental health on the Internet platform should be updated and replaced in a timely manner. For college students' messages on the website platform, they should reply in time and provide specific suggestions based on the actual psychological needs of college students. At the same time, with the help of internet technology teachers, we have further realized the joint maintenance of website content and technology. In addition, resource sharing is determined by the characteristics of the openness of the Internet. With the help of the "one-stop" mental health education service supermarket website, the psychological health education network system of this university has been completed. At the same time, under the guidance of psychological teachers, college students can use the Internet platform to master their own psychological problems. When communicating and exchanging with others, they can fully improve their own psychological problems with the help of various psychological education resources.

\section{B. Moral Education and Follow-up Counseling}

Shandong universities pay more attention to moral education in the maintenance of the "one-stop" mental health education service supermarket website. The website has established a logistics team to regularly inspect and supervise the interactive area of the website. When it finds negative and passive comments in the interactive commentary area, it will promptly eliminate it, and appropriately consider banning speaking according to the severity of the review. During the construction of the "one-stop" mental health education service supermarket, the school has fully promoted the students to carry out beneficial online exchanges through moral education and guidance. In addition, in the field of follow-up counseling, they master the mental health problems of college students mainly through the "one-stop" mental health education service supermarket, to find out the psychological problems of college students and implement follow-up counseling, which provides a strong guarantee for the rational development of college students' psychological health education.

\section{CONCLUSION}

Nowadays, the mental health of college students has received widespread attention from all walks of life. In order to improve the mental health of college students, many colleges and universities have applied various techniques in the development of psychological health education for college students. Among them, Internet technology is a common and important means. When using the Internet technology to achieve the psychological health education for college students, there are many forms of application. In view of the current status of application of Internet technology, this article focuses on the Internet technology platform of "one-stop" mental health education service supermarket, to study the situation of a college carrying out the education of college students' psychological health through the application of Internet technology. During the research period, through the analysis of the construction goals, design requirements, storage-style network automatic service platform of "one-stop" mental health education service supermarket, the author comprehensively grasps the status quo of the construction of the Internet technology platform model in the school, and points out the matters needing attention in building the platform. I hope that under this relevant study, we can provide suggestions for improving the application of Internet technology in the psychological health education for university students.

\section{REFERENCES}

[1] Ai Bo, Wang Tao. College Students' Mental Health Education and Response to Psychological Crisis: A review of "College Students' Psychological Health Education" [J]. Journal of The Chinese Society of Education, 2018,05 (1). 艾波, 王涛.大学生心理健康教育与心理 危机应对一一评《大学生心理健康教育》[J].中国教育学刊, 2018, 05(1).

[2] Zhang Ke, Yang Meng. The Value of "Hehe" Culture to the Psychological Health Education of College Students [J]. Chinese Adult Education, 2017, 02 (9): 88-91. 张可，杨萌. “和合” 文化对 大学生心理健康教育的价值[J].中国成人教育, 2017,02(9):88-91.

[3] Gong Yan, Zhang Mingzhi, Chen Juan. The Choice of Practice Approaches to College Students' Mental Health Education in China at the Present Stage[J]. Theory and Practice of Education, 2016, 01(24). 龚燕, 张明志, 陈娟.我国现阶段高校大学生心理健康教育实践 路径的选择 $[\mathrm{J}]$.教育理论与实践, 2016, 01(24).

[4] Li Li, Yang Yuyu, Zhang Yan. Exploration of Psychological Health Education Model in China's Universities: A Perspective of Group Psychological Health Education[J]. Academic Exploration, 2017, 04(8): 150-156. 李莉, 杨玉宇, 张燕.我国高校心理健康教育模式 探索——群体心理健康教育视角 [J]. 学术探索, 2017,04(8):150156.

[5] Peng Yanan, Xi Juzhe, Zuo Zhihong. Status, Problems and Prospects of Psychological Service App in Internet+Background[J]. Chinese Journal of Clinical Psychology, 2017, 25(2):333-336. 彭雅楠, 席居 哲，左志宏.互联网+背景下心理服务类 APP 的现状、问题及展望 [J].中国临床心理学杂志, 2017, 25(2):333-336.

[6] Wang Shumei. Exploration of Education in the "Internet +" Era of College Students' Psychological Health Problems [J]. Vocational and Technical Education, 2016, 37 (35): 66-68. 王淑梅. “互联网+”时 代大学生心理健康问题的教育探析 [J].职业技术教育, 2016, 37(35):66-68.

[7] Yu Guoliang, Wang Hao. Thoughts on the Psychological Health Education Concept of College Students in the Socail Transition Period: Interview Evidence[J]. Heilongjiang Researches on Higher Education, 2017, 08(3): 114-116. 俞国良, 王浩.社会转型期大学生 
心理健康教育观念的思考: 访谈证据 [J]. 黑龙江高教研究, 2017,08(3):114-116.

[8] Zhang Liang, Xiao Dongmei, Xiang Nan, et al. The Application of Positive Psychology in the Education of Mental Health in Universities_- Taking Northeast Agricultural University as an Example[J]. Journal of Northeast Agricultural University(Social Science Edition), 2017,(6): 85-89. 张亮, 肖冬梅, 相楠, 等.积极 心理学在高校心理健康教育中的应用一一以东北农业大学为例 [J]. 东北农业大学学报(社会科学版), 2017,03(6):85-89.

[9] Mu Honglang, Chen Chunxiao. Research on the Theory and Practice of Mental Health Education of College Students: A Review of "The Theory and Practice of Psychological Health Education for College Students in the New Era" [J]. Higher Education Exploration, 2017, Vol.12 (12). 穆宏浪, 陈春晓.大学生心理健康教育理论与实践研 究——评《新时期大学生心理健康教育理论与实践探究》 [J]. 高 教探索, 2017,05(12).

[10] Chen Xinxing. The Ethic Dilemma of Counselors in Carrying out Mental Health Education among College Students and the Responses[J]. Journal of Ideological and Theoretical Education, 2016, 04(2): 148-150. 陈新星. 辅导员开展大学生心理健康教育的伦理困 境及应对[J].思想理论教育导刊, 2016,04(2):148-150. 